\title{
Global market and income gaps between industries: evidence from finance industry and manufacturing industry
}

Xue Li

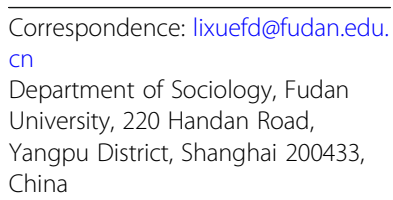

Correspondence: lixuefd@fudan.edu. China

\begin{abstract}
The income gap among industries in China is usually explained by the theory of segmented labor market. However, this perspective cannot explain why the finance industry has the highest average income among the monopoly industries, while the manufacturing industry has much lower incomes than any other competitive industry. This paper argues that it can be explained by the way China participates in the economic globalization. Liberalization of the manufacturing industry and protection of the finance industry are China's strategies in dealing with opportunities and challenges of economic globalization. This paper compares the average incomes of monopoly and competitive industries, as well as that of finance and manufacturing. Analyses of panel data spanning from 2000 to 2014 show that the bigger the size of foreign trade, the higher the average income of the finance industry, and the lower the average income of the whole monody industries; at the same time, FDI reduces the average income of the manufacturing industry. This research advances the literature of segmented labor market by pointing out that income inequality between industries in China should be understood in the context of economic globalization.
\end{abstract}

Keywords: Economic globalization, Trade, Foreign direct investment (FDI), Labor market segregation, Finance industry, Manufacturing industry

\section{Introduction}

From the very beginning, China's transition into a market economy has been oriented towards opening up to the global market. Between 1980 and 1990, in order to attract foreign investment and introduce advanced technological and administrative experience, China established five special economic zones in Shenzhen, Zhuhai, Shantou, Xiamen, and Hainan, respectively. Meanwhile, the Yangtze River Delta, the Pearl River Delta, and Southern Fujian Delta were established as coastal open economic zones. Developmental projects were also launched in Putong, Shanghai. Since the mid-1990s, foreign trade has gradually become a critical instrument for stimulating economic growth and creating employments, as the country adopts an export-oriented strategy of economic development (Yuan 2010). As the Chinese market is increasingly integrated into the global market, the global economy has significantly shaped a variety of sectors in the Chinese economy, as

(c) The Author(s). 2019 Open Access This article is distributed under the terms of the Creative Commons Attribution 4.0 International License (http://creativecommons.org/licenses/by/4.0/), which permits unrestricted use, distribution, and reproduction in any medium, provided you give appropriate credit to the original author(s) and the source, provide a link to the Creative Commons license, and indicate if changes were made. 
well as inequalities among economic sectors. For example, consistent with the trend of financialization in the global economy, the finance industry in China has also gone through a dramatic expansion, in both size and profitability. The financial sector has occupied an increasingly important position in the national economy (Wang 2014; Yang 2018). In contrast, the manufacturing sector, once characterized by its rapid growth thanks to the country's opening up, is facing challenges such as declining profit margin and capital outflow. The real economy of the country has shown signs of stagnation, in contrast to the paper economy. The profitability of an industry determines its income level. These new trends have led to a dramatic increase in the income gap between the finance and the manufacturing industries. As shown in Figure 1, since the mid-1990s, the financial sector in China enjoys the highest income level among all the economic sectors. Meanwhile, the income level of the manufacturing sector is not only lower than the financial sector but also lower than other competitive industries such as food catering and the service sector. What are the forces that drive increasing sectoral income inequality? What factors cause the advantage of the financial sector over the manufacturing sector?

The income inequality among industries-in other words, the segmentation of the labor market-is key to understanding the transition to a market economy in China. It is also a highly important sociological issue. The government maintains firm control over key economic sectors in order to be able to lead the economic reform and maintain the state power, using strategies such as state monopoly and industrial access control system. Previous research has shown that the average income level of the monopolistic sector is usually higher than that of the competitive sector (Qi and Liang 2016). A study based on the data from the Chinese Household Income Project (CHIP) found that, even after controlling individual characteristics, the sectoral factor was still significantly associated with income inequality. Monopoly, as a structural factor, had a higher explanatory power than human capital in explaining income inequality (Wang and Luo 2012; Hao and Li 2006).

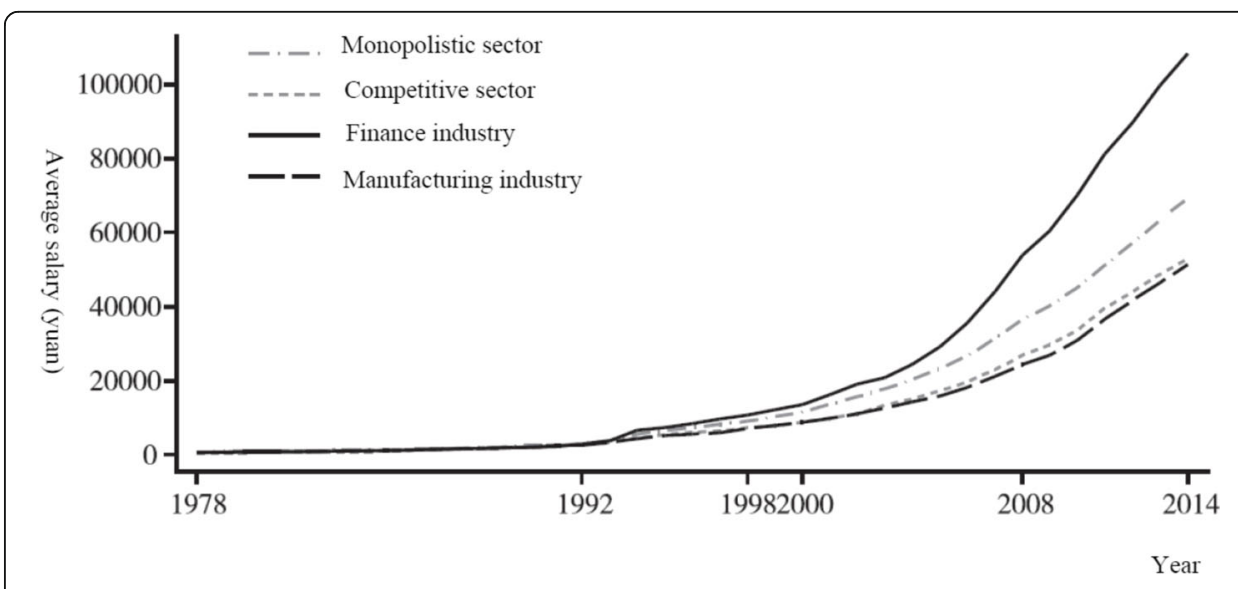

(Source: China Statistical Yearbook, 2000-2015, calculated by the author)

Fig. 1 Average wage of different sectors: 1978-2014 
That being said, the perspective of the segmented labor market cannot explain the inequalities within the monopolistic and the competitive sectors. In other words, why does the financial sector enjoy the highest average income level within the monopolistic industries, and why is the average income level of the manufacturing sector lower than other competitive industries? Some scholars used sectoral characteristics to explain the phenomenon. However, other monopolistic industries, such as electric power, hydraulic industry, and mining, may have a higher degree of monopoly than the financial sector (Zhang 2004); these industries were the priority of government investment in the 1980s and 1990s, and their importance to the national economy was no less than the financial sector. Yet, the average income level of these industries was lower than the finance industry. Others attributed the sectoral income inequality to productivity- but the productivity of the finance industry in China is not only lower than their counterparts in advanced industrialized countries but also lower than some competitive industries in China, including the manufacturing industry (Xie and Yin 2002).

This article argues that the respective positions of the finance and the manufacturing industries in sectoral income distribution should be understood in the context of the economic globalization. As China is increasingly integrated into the global market, the state has to respond to the challenges and opportunities created by the globalization, which is translated into policies and legal frameworks (such as industrial policies) that have impacts on the sectoral composition of income. Figure 2 summarizes this process. First, as a response to the impacts of global competition, the state establishes a monopoly in several key industries. Yet, the global competition introduced by China's economic opening up places some constraint on the income level of these monopolistic industries. Second, China's manufacturing industry actively participates in global competition and attracts foreign direct investment (FDI). The global competition suppresses both its profit margin and its average income level. Third, the enormous financial risk emerged in foreign trade and foreign investment obliges the Chinese government to reinforce the monopolistic character of the financial sector. The government also directly assists the sector to raise its efficiency, to promote innovation, and to reduce risks. All these preferential policies contribute to the advantage of the financing industry over other economic sectors in terms of income level. In other words, as the

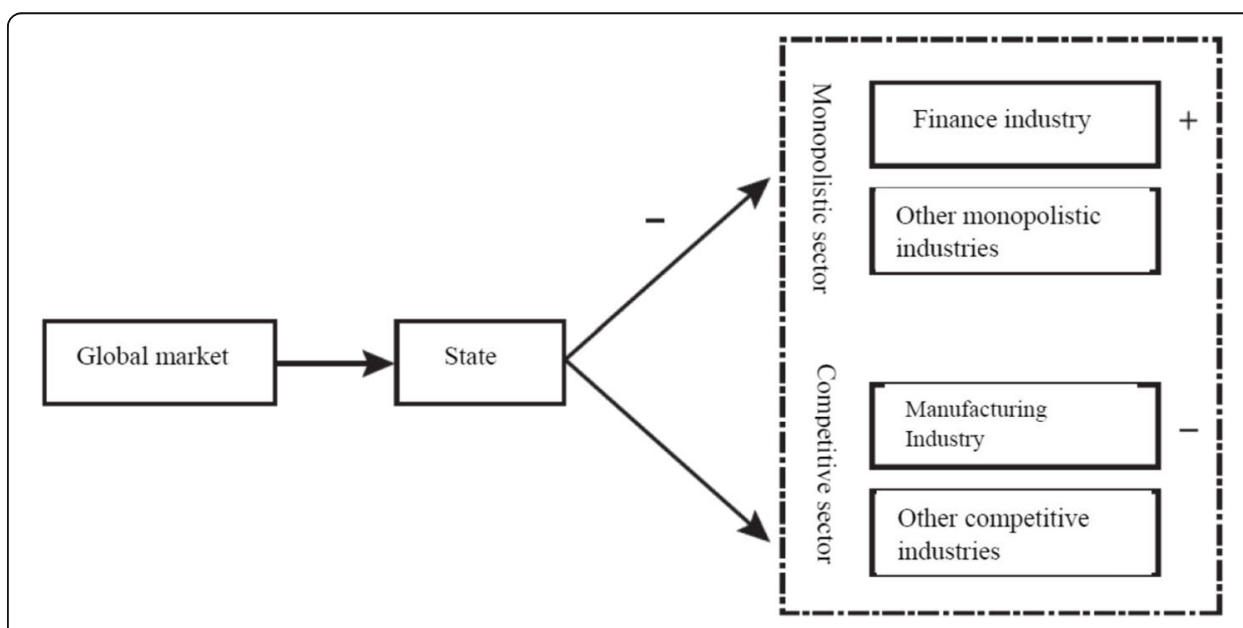

Fig. 2 Global market, state, and segmentation of the labor market 
government foments and regulates the market, the challenges and opportunities generated in the global market have reshaped the boundary and meaning of the so-called state interest, as well as the state-market relations. This also has specific impacts on the income level of certain economic sectors.

\section{Economic globalization and China's transition to market economy}

\section{Segmentation of the labor market and inter-sectoral income inequality}

Although the market plays an increasingly important role in resource allocation in China (Nee 1989, 1991, 1996), the state has never stopped to shape the market. How the state influences the market varies from time to time (Bian and Logan 1996; Rona-Tas 1994). China's market-oriented reform takes a gradualist approach, and the introduction of the market mechanism varies largely according to factors such as geographic region, form of ownership, and industry (Xie and Hannum 1996; Li et al. 2016; Wang and Cui 2010; Luo and Li 2007; Wu 2011).

Yet, existing research neglects the current wave of economic globalization. These studies have not addressed how the global market influences the trajectory of Chinese reform. Given that China's transition to a market economy unfolded in tandem with the country's insertion into the global economy, it is critical to examine the mechanisms through which the economic globalization shapes China's transition. As will be discussed later in this article, the current globalization sets a boundary for-and reshapes-what is considered as national interests. This will further influence government policies for the finance and the manufacturing industries, as well as their sectoral income level.

\section{What is economic globalization?}

Trade and investment are the most important and common economic activities. Economic globalization means that such activities are more frequently carried out across national borders (Lim and Tsutsui 2012). After the dissolution of the Bretton Woods System in the 1970s, the international financial regime has been characterized by the Dollar Standard System and the floating exchange rate system. These two systems constitute the foundation of the current global economic system. They also generated two important consequences, namely, global reorganization of the manufacturing sector and liberalization of the financial sector. Previously, under the Bretton Woods System, countries usually keep their manufacturing sector within their national boundary, because manufacturing exports were critical for balancing the country's current account and controlling trade deficits. In contrast, currently, under the Dollar Standard System, countries must hold dollars and the US economy runs with debts. The USA seeks to manage its deficits by employing a variety of financial tools to finance from abroad. As a result, it became unnecessary to keep the manufacturing industry inside the USA territory.

The liberalization of the financial sector has not only generated huge profits for the financial capital but also created potential risks for open economies like China which heavily depend on the global market. First, if the country runs a trade deficit, its demand for US dollar will increase; hot money from the international financial market will flow in and out of the country and make huge profits. This 
can worsen the country's deficit of US dollar and cause a liquidity crisis. Second, a trade surplus will push a country to purchase a large amount of debts and bonds denominated in US dollar, in order to maintain the value of its assets in foreign currency. When the bonds mature, a large amount of currency will enter the domestic financial market, which can increase financial speculations and generate huge risks. Third, international hot money can flow into China's domestic market, disguised as foreign trade or FDI, which becomes another source of financial risks for the country. Fourth, China has accumulated an FDI stock of 1 trillion US dollars over the past decades. A withdrawal of the FDI may cause a liquidity crisis for the country.

The global competition in the manufacturing sector and the high risk of the financial sector are not only the basic characteristic of the current economic globalization; they also constitute the external condition for China's market transition.

\section{Monopolistic and competitive industries under economic globalization}

China's economic reform is characterized by its capacity to utilizing the resources and opportunities generated by globalization. Now China ranks No. 1 in the world in international trade. It is also the largest destination of foreign investment and the second largest source of foreign investment. Foreign trade, including exports and imports, represents China's participation in the global market and competition. Foreign investment often pursues long-term interests in the economy of its receiving country and tends to produce for the local market. The size of FDI is a useful indicator to measure the competition and collaboration between foreign investors and Chinese enterprises, as well as its impacts on income distribution.

The economic globalization has expanded global competition and to a certain extent reduced the advantage of the income level of monopolistic sectors. Although monopolies are not totally free from competitions (e.g., the competition among China Mobile, China Unicom, and China Telecom), they are largely protected by their monopoly status. Notwithstanding, foreign trade and FDI introduced at least some pressure of competition from the international market to these monopolies. First, in the export industries, monopolies tend to suffer lower productivity and higher costs, and exporting companies must reduce labor costs in order to make their products more competitive. Second, the competition from imported goods affects the production and sales of the domestic industry and will reduce the wage rates in these industries. Third, some foreign or mixed capital companies are fortunate enough to enter a few monopolistic sectors, and their productivity and administrative capacity will also affect local state enterprises and lower the income level of those sectors.

For these reasons, this article proposes the following hypotheses:

Hypothesis 1: the degree of participation in economic globalization has a negative impact on the sectoral income level.

Hypothesis 1a: the larger the volume of foreign trade, the lower the average income level of the monopolistic sector.

Hypothesis 1b: the larger the volume of FDI, the lower the average income level of the monopolistic sector. 
For competitive industries, the effects of economic globalization are often not significant. This is because although wages in some industries such as manufacturing may be suppressed by global competition, for many other competitive industries (e.g., food catering, the service sector), as their productivity is high, the global competition has minor effects on their average income level.

\section{China's manufacturing industry in the context of economic globalization}

Foreign trade and FDI can often substitute each other (Zhang and Guo 2004). Foreign investment and foreign trade in China are largely concentrated in the manufacturing sector, particularly the labor-intensive industries (Jiang and Li 2010). Although machinery and electronic products have increased their share in the exports of the country, most of these goods are only assembled products with no original intellectual property right (Yuan 2010).

Two opposing positions exist among scholars regarding the relationship between foreign trade and the income level of the manufacturing sector. The first one, which is based on the theory of international trade, underscores the positive relationship between foreign trade and the income level of the manufacturing sector. According to this view, both parties involved in foreign trade can harness their comparative advantages and benefit from the trade. As China is labor-abundant but faces a scarcity of technology and capital, the country should export labor-intensive products and import capital-intensive goods. Because the Chinese manufacturing sector is still predominantly labor-intensive with a low technological level, non-skilled labor will see an increase in their wages, which will further raise the average income level of the manufacturing industry. Based on this idea, Xu (2003) predicted an improvement in income distribution after China's admission into the World Trade Organization. Wei (2002) found that participation in the global economy particularly benefited the lowand middle-income groups, which would lead to an improvement in income distribution.

The opposing side contends that foreign trade is more likely to benefit skilled labor, technicians, and male workers, and thus will augment the income inequality between these groups and the non-skilled workers. Given that the manufacturing workforce in China is predominantly non-skilled labor, it is expected that foreign trade will hinder the wage increase for this sector (Feenstra and Hanson 1997).

The bulk of existing research on China identifies a positive relationship between income inequality and foreign trade and attributed this to the higher return on foreign trade to skilled labor and technicians. Empirical evidence suggests that foreign trade expands the income gap between skilled and non-skilled labor (Zhao 2003), technicians and non-technicians (Bao and Shao 2008), and between male workers and female workers (Liu and Li 2012), as well as urban residents (characterized by higher level of education and human capital) and rural residents (Zhao and Zhang 2013).

Scholars who focus on income find that the effect of foreign trade on wages varies with time. In recent years, foreign trade has a negative impact on the income level of the manufacturing industry, as well as the income level of the low- and middle-income population. In the late 1980s and early 1990s, foreign trade in the coastal region once created a large number of job opportunities and attracted migrant workers from the 
rural area of the interior provinces. The transfer of the redundant labor from the rural area to the urban area significantly raised the wage level of the manufacturing sector (Wang 2001). Data from recent years, however, suggest that this trend has been reverted. Data between 1998 and 2011 show that exportation did not significantly improve the wage level of the manufacturing sector (Bao et al. 2011). Another household survey (1998-2001) reveals that foreign trade has widened the income inequality in China since the country's admission into the WTO (Han et al. 2012).

Students of globalization argue that wages in the manufacturing sector are suppressed due to the competition among developing countries in the global market. In the context of economic globalization, enterprises in these countries not only have to compete with domestic companies but also with those in the global market. The pressure of international competition urges companies to reduce labor costs and to engage in the so-called race to the bottom (Guan 2002). Following China's admission into the WTO in 2001, Chinese companies compete in the global economy in a broader and deeper way. As a result, wages in the manufacturing sector are suppressed, as cost control became particularly important for manufacturers which seek to export their products to the global market.

Importation also has a negative effect on income. Since the country's admission into the WTO, China has significantly reduced its trade restrictions, such as tariffs, import quotas, and other non-tariff trade barriers. These factors combined to increase the country's imports. As many of the previous trade restrictions aimed to protect the products that advanced industrialized countries had advantages over China, such as automobiles and electric equipment, an increase in imported products was a heavy blow to these industries and caused widespread bankruptcies and massive layoffs (Hai 2001). The increase in the unemployment rate also has a negative impact on the wage level of the manufacturing sector.

In sum, researchers who focus on comparative advantages tend to emphasize the positive effects of foreign trade on the wage level of the manufacturing sector. Those who focus on human capital (skilled versus non-skilled workers), technological innovation, and market competition tend to agree that foreign trade suppresses the wage level of the manufacturing sector. Based on these viewpoints, this article proposes the following hypotheses:

Hypothesis 2: the level of foreign trade has a significant impact on the average income level of the manufacturing sector.

Hypothesis 2a: Based on theories of comparative advantages and international trade, the higher the level of foreign trade, the higher the average income level of the manufacturing sector.

Hypothesis 2b: Based on theories of competition and human capital, the higher the level of foreign trade, the lower the average income level of the manufacturing sector.

As scholars disagree over the nature of foreign capital, they also have different views over the effect of FDI on wages.

The mainstream economist argues that "capital is capital," which is free from the influence of power structure or social relations. Thus, whether the capital is national or foreign should have no effect on income distribution. It is expected that the influx of 
foreign capital can create jobs and increase the wage level of the manufacturing sector. Data from Mexico in the period 1990-2000 show that foreign capital raised the income level of the working class (Jensen and Rosas 2007). There are two mechanisms through which foreign capital affects wage level: first, foreign enterprises will bring a large amount of capital, which makes capital less scarce. This will reduce the economic return on capital and raise the return on labor. Second, labor-intensive enterprises harness the comparative advantages of the developing countries, create jobs for nonskilled workers and raise their income level.

Modernization theories also agree that, in general, foreign capital from developed countries can raise the wage level of various economic sectors (including the manufacturing industry) and promote modernization in underdeveloped countries. Even though developing countries must suffer some temporary pain during their transition to modernity, they are expected to eventually achieve the same living standard of developed countries (Kentor 2001).

Most sociologists oppose to this viewpoint. They disapprove the argument of capital is capital, contending that the inflow of foreign capital is carried out in a set of power relations. The inflow of foreign capital alters the industrial structure of the receiving country and suppresses wage level. In opposition to economists' argument on the positive relationship between foreign capital and wage level, dependency theorists distinguish the short-term and long-term impacts of foreign capital. They argue that although in the short term, foreign capital can create jobs and reduce the scarcity of capital, in the long term, the influx of foreign capital can distort the economic structure of the receiving country, often in favor of external sectors such as mining and manufacturing (Dixon and Boswell 1996). These external sectors may have achieved a certain level of development. However, as the foreign capital seeks to maximize profits, it has little incentive to expand investment or contribute to tax revenues or infrastructure development in the host country. Moreover, it has a strong incentive to maximize profits by reducing labor cost (Curwin and Mahutga 2014).

The world system theory underscores the geographic division of labor between developing and developed countries. This theory views the domination and exploitation of developing countries by developed countries as the source of low wages in developing countries. In this system, whereas developed countries (referred to as "core countries") are specialized in producing high-tech products, developing countries (referred to as "periphery countries") are specialized in providing raw materials and labor-intensive products. Developing countries are forced to remain at the lower end of the global production chains (Wallerstein 1974). The fact that foreign capital is only interested in maximizing profits leads to the low wage level of the external sectors in developing countries.

In theory, FDI may have some positive externalities and stimulate technological innovation in China, which may further lead to higher productivity and higher wages. However, empirical research shows that the main effects of FDI in China are capital accumulation. The industrialization in China is still mainly driven by the simple expansion of investment (capital-driven, instead of technology-driven). The role of FDI in technological progress in China is only marginal (Li and Zeng 2009).

In sum, economists who focus on the economic nature of capital tend to underscore the positive relationship between foreign investment and the income level of the 
manufacturing sector. On the contrary, sociologists pay much attention to the political nature of foreign capital. They argue that the inflow of foreign investment can suppress the wage level of the manufacturing sector in host countries. Based on these contrasting viewpoints, this article proposes the following hypothesis:

Hypothesis 3: FDI has significant impacts on the income level of the manufacturing sector.

Hypothesis 3a: Based on modernization theory, the higher the level of FDI, the higher the average income level of the manufacturing sector.

Hypothesis 3b: Based on the dependency theory and the world system theory, the higher the level of FDI, the lower the average income level of the manufacturing sector.

\section{China's finance industry in the context of economic globalization}

Against the backdrop of economic globalization, the finance industry enjoys a high level of income and profit globally. The financial sector is the highest-paying industry not only in developed countries such as the USA and France but also in developing countries such as China. Most economists attribute this phenomenon to the market mechanism, such as the expansion of the financial market, the increasing demand for financial services as the result of expanding international trade, the scarcity of talents in the financial sector, and the high productivity of the financial sector (Manova 2012).

In opposition, sociologists focus on the power structure in which the market is embedded. The market equilibrium is not natural, nor does it happen automatically. On the contrary, the market consists of a set of institutional arrangements, and reflects the power relationships among various stakeholders (Fligstein 2001). Based on this understanding, scholars attribute the high wages in the financial sector to two processes: the generation and the distribution of economic rent. Here, economic rent refers to the extra revenues generated beyond the perfect competition of the market (Sorensen 2000). The primary goal of capitalists is to maximize profits. To achieve this goal, rather than engaging in market competition, capitalists manage to avoid competition by creating favorable market conditions and maintaining the monopoly. In this process, capitalists in the financial sector become increasingly powerful and occupy an advantageous position over the industrial capitalist. Financial capitalists can persuade national and state governments to forgo its previous rigorous monetary policy to deregulate the financial sector and financial activities, to relax regulations over speculation, and etc. All these preferential policies generate enormous profits for the financial sector in the short term. Meanwhile, the distribution of economic rent is a negotiated social process (Carruthers and Kim 2011). As the financial sector becomes increasingly powerful, it also occupies a favorable position in the redistribution of economic rent. This is particularly the case for institutional investors, commission-based employees, and bankers (Tomaskovic-Devey and Lin 2011). In sum, sociologists focus on how the growing power of the finance industry leads the government to implement preferential policies in its favor.

The high wage level of the financial sector in China, on the other hand, has much to do with how the challenges of economic globalization have reshaped government 
policies. The importance of the financial sector in the current wave of globalization, as well as the high risk and profitability of the financial sector, combine to shape government financial policies. The Chinese government not only consolidates the monopolistic character of the financial sector but also helps the sector to repay its debts, to improve its efficiency, as well as to learn innovative financial tools from Western countries. All these factors contribute to the high-income level of the financial sector in China.

While the financial sector is characterized by its high risk, it should be noted that the financial sector in China has only recently undertaken its transition from the planned economy to the market economy. Its performance is not optimistic. According to the statistics from the China Banking Regulatory Commission, the non-performing loan (NPL) ratio of the four major state-owned banks in China reached as high as $40 \%$; these banks were technically on the verge of bankruptcy (Xie and Yin 2002). The current Chinese financial sector was created as the result of the country's insertion into the global economy. Prior to economic reform, the financial sector in China only assumed the role of banking. The People's Bank of China was the only bank in the country. ${ }^{1}$ The banking system at the time did not have to face the risk of loans, nor to operate on the principle of profit maximization. The monetary supply and interest rates were established by the People's Bank of China; the monetary demand was determined by the planned economy. Bank branches were required to remit their revenues to upper-level branches. The financial market was non-existent. In sum, the banking system in the pre-reform era served no more than an instrument to fulfill economic plans. Banks had little autonomy in decision-making, and they did not play an independent role in adjusting the economy (Song 2008). From the beginning of the economic reform and opening up to the 1997 Asian Financial Crisis, the development of the financial sector in China centered around establishing and consolidating the three major finance industries, namely, the banking system, the stock market, and the securities industry, so that the financial sector could serve the purposes of economic opening and economic development. The Chinese finance industry took an extensive mode of growth, which heavily relied on the expansion of financial institutions and personnel, with very little regard to risks. Between 1989 and 1997, the volume of the loans issued by the four major state-owned banks increased by 4.63 times, but the profit decreased by $63 \%$, from 24.24 billion Yuan to 8.51 billion Yuan, and the administrative costs increased by 8.7 times. $^{2}$

The 1997-1998 Asian Financial Crisis, the admission of China to the WTO, and the US Financial Crisis in 2008, were external shocks to the Chinese financial sector. The Chinese government had to face seriously the challenges imposed by the economic globalization on the financial market. The government became aware that the chronic low competitivity and high risks combined to make China's financial market vulnerable to external shocks. Thus, following the 1997 Financial Crisis, the Central Committee of the Communist Party and the State Council held the first national meeting on the financial sector, in which much emphasis was placed on "effectively avoiding financial risks" and "accelerating the establishment of a modernized financial system." Soon after China's admission to the WTO, the Central Committee of the Communist Party held the second national meeting on 
the financial sector in which various policies were established to enhance the competitivity of the country's financial sector.

First, measures were taken to maintain and reinforce the monopolistic character of the financial sector. People's Bank of China enhanced its role as the central bank. Four major state-owned, specialized banks were founded, together with 12 commercial banks in which state enterprises or local governments owned the bank's outstanding stock. ${ }^{3}$ Meanwhile, barriers to entry were raised against foreign banks and more restrictions were imposed on their activities in China. ${ }^{4}$

Second, the banking sector exercises firm control over interest rates in order to maintain its high profitability. Banks take up to $85 \%$ of the profits generated by the entire financial sector, and $70 \%$ of their profits come from the interest rate spreads. In China, interest rates have always been under government control, ${ }^{5}$ and banks obtain profits from the gap between interest rates for savings and those for loans. As a result of government control, interest rates in China cannot correctly reflect the scarcity of the resources, and loans and savings are not subject to market forces. Meanwhile, due to the barriers to entry, Chinese banks maintain their monopolistic position. Companies find very few options when they seek loans. They are usually in a weak negotiation position with loan agencies and must passively accept the terms and conditions of the loan.

Third, the Chinese government uses its own resources to help banks to repay their debts. The Basel Accords established a minimum capital adequacy ratio of $8 \%$. To help the Chinese banks to meet this requirement, between 1990 and 2005, the government recategorized 243.75 billion Yuan of debts of the four major state-owned banks as government debts. Between 2003 and 2005, the government injected 60 billion US Dollars from the country's foreign reserves to Bank of China, China Construction Bank, and Industrial and Commercial Bank of China. Nevertheless, China still has one of the highest ratios of non-performing loans in the world (Xie and Yin 2002; Zhou 2007).

Fourth, the government actively promotes the stockholding system in the four major state-owned banks and listed them on the stock market. This attracts an enormous amount of funds for these banks and improves their administrative capacity. More importantly, the introduction of foreign equities-in this case, Bank of America and Scotia Bank-allows the national banks to learn advanced technology, administrative experience, and innovative financial tools in a more direct and in-depth manner. This has a positive impact on the profitability of China's banking sector.

Fifth, control over exchange rates and capital accounts are rigorously enforced, with the purpose of reducing risks and improving the profitability of the banking sector. As the Chinese economy is highly dependent on the global market, the international financial capital pressures the Chinese government to marketize the exchange rates and to liberalize capital accounts for foreign investors. Currently, China has a "controlled" floating exchange rate regime, which establishes that the fluctuation of the dollar-yuan exchange rate should not exceed $2 \%$. This is essentially a fixed exchange rate regime. The control over capital accounts imposes restrictions over transnational transactions and transfers of funds. These two regulatory mechanisms, to a certain extent, insulate the financial sector of China from the international financial market, which reduces risks and fluctuations of the economy.

It is obvious that consolidating the monopolistic character of the financial sector is consistent with the national interest. This differs sharply from the era of planned 
economy, when the financial sector was a regular economic sector and it was the heavy industry that enjoyed preferential treatment from the government. Currently, the Chinese financial sector enjoys not only a higher income level compared to other sectors, but also additional preferential policies, as the government intends to improve its productivity and competitivity. The high wages in the financial sector are the result of its monopoly, high efficiency, advanced technology, and low risk. In sum, as China becomes increasingly inserted into the global economy, it will face increasing potential financial risk. This will further raise the importance of the financial sector, and the government preferential policies will be more effective to increase the income level of the financial sector. Accordingly, this article proposes the following hypothesis:

Hypothesis 4: the higher the degree of economic globalization, the higher the income level of the financial sector.

Hypothesis 4a: The higher the level of foreign trade, the higher the income level of the financial sector.

Hypothesis 4b: The higher the level of FDI, the higher the income level of the financial sector.

\section{Data and methods}

This research draws on provincial-level panel data for the years 2000 to 2014. For example, the data for Beijing in 2014 consists of observation. The dataset covers all the 31 provinces, autonomous regions, and direct-administered municipalities of Mainland China. Missing data are concentrated in the sex and the education level of the labor force for some provinces in certain years. These missing data are to a certain extent random. In sum, the dataset used in this research reflects the country's reality the provincial level for the years 2000-2014.

This article uses fixed-effect models, which is often used in the analysis of panel data in generalized linear regression. Province and year fixed effects are controlled. Interclass correlation is treated with the calculation of clustered standard errors. Based on the result of the Hausman test, this research adopts the fixed-effect model. Finite difference is used to ensure the stability of time series for the variables with unit roots. Regarding the possible endogeneity caused by missing variables, the dependent variables are added to the regression model as lagged variables. The lagged variables represent the unobserved factors of individual heterogeneity and historical factors. Instrumental variables are introduced to identify the "reverse causality"-that is, low wages in the manufacturing sector may also cause a higher degree of foreign trade and FDI. ${ }^{6}$ All the independent variables in the regression model are altered to lag by a year, given that the independent variables in the panel data have lagged effects (Brady et al. 2005; Haggard and Kaufman 2008). Below is the regression model:

$$
\Delta Y_{t}=\beta_{0}+\beta_{1} Y_{t-1+} \beta_{2} X_{t-1}+\varepsilon_{t},
$$

where $\Delta \mathrm{Y}_{\mathrm{t}}$ is the first-order difference of the dependent variable $Y$ between year $\mathrm{t}$ and year $\mathrm{t}-1, \beta_{0}$ is the intercept, $Y_{t-1}$ is the lagged variable, and $X_{t-1}$ is the lagged version of the matrix of the independent variables.

The sectoral average salary is used as the dependent variable ${ }^{7}$ to measure the income inequality among different sectors, including (1) average salary of the monopolistic 
sector, (2) average salary of the competitive sector, (3) average salary of the finance industry, (4) average salary of the manufacturing industry, (5) average salary of the nonfinance monopolistic industries, and (6) average salary of the non-manufacturing competitive industries. Real wages are used instead of nominal wages to exclude the effects of inflation. For the sectoral classification, we refer to the criteria used in $\mathrm{Li}$ and $\mathrm{Gu}$ (2011) and Li et al. (2016). ${ }^{8}$ Here, monopolistic industries include electricity, heat, gas and water production, and supply industry; transportation, storage, and postal services; information transmission, software, and information technology services; water conservancy, environment, and public facilities; education, health care, and social work; culture, sports, and entertainment; scientific research and technical services; and public administration, social insurance, and social organizations. Competitive industries include construction, manufacturing, wholesale and retail trade, accommodation, and catering industry; real estate; leasing and business services; and resident services, repairs, and other services.

In globalization studies, two indicators are often used to measure the influence of economic globalization on the national economy: (1) exports and imports as a percentage of GDP, and (2) FDI as a percentage of GDP. These two indicators are used in this research as independent variables to measure the influence of economic globalization on the average income level of the monopolistic and the competitive sectors, as well as of the finance and the manufacturing industries (e.g., Brady et al. 2005).

Moreover, four control variables are introduced to take into account the factors that may influence sectoral income levels: (1) level of economic development: the more developed the economy becomes, the higher the income level will be, which applies to all sectors. In this article, GDP and GDP per capita at the provincial level (logarithm taken) will be used to measure the level of economic development. (2) Labor force characteristics of the sector: the higher the education level of its workforce, the higher the sectoral income level will be. In this research, the education level of the labor force is measured by the percentage of the workforce that has a higher education degree. As, in general, men occupy an advantageous position over women in terms of wages, this research also takes into account the percentage of male workers in the workforce. (3) The importance of the sector: the overall output of the sector as a percentage of GDP is used to measure the importance of the sector. The idea is that a higher contribution to the GDP may lead to a higher sectoral income level. Finally, (4) significant events. The level of foreign trade and FDI in China fell significantly after the 2008 Financial Crisis. Despite its moderate increase in the following years, it never recovered to its peak in 2006. This variable is introduced to control the impacts of the financial crisis on sectoral income levels (years before 2008 are set as 0 , and years after 2008 are set as 1).

\section{Findings and analysis}

The analysis shows that economic globalization has a significant impact on sectoral income levels in China. First, the size of foreign trade is negatively correlated to the average income level of the monopolistic sector. Exports and imports increase competition and reduce the capacity and volume of the economic rent that these sectors can extract, which also lowers the income level of these industries. Second, the size of foreign trade is positively associated with the income level of the finance industry. The high 
dependency of the Chinese economy on foreign trade has generated enormous financial risks. The government responds with consolidating the monopolistic character of the financial sector and taking a number of preferential policies in favor of the sector. All this significantly raises the income level of the finance industry. Third, FDI significantly suppresses the average income level of the manufacturing industry. Therefore, Hypotheses 1,3 , and 4 are supported to different extents.

\section{The monopolistic and the competitive sectors under economic globalization}

Let us begin by examining the impacts of economic globalization on the average income level of the monopolistic and the competitive sectors. Models 1, 2, 4, and 5 from Table 1 show the effect of foreign trade and FDI. ${ }^{9}$ Models 1 and 2 show that foreign trade is negatively correlated to the income level of the monopolistic sector, and the correlation is significant at the 0.05 level. Every percentage point increase in the tradeto-GDP ratio is associated with a $0.03 \%\left(=1-\mathrm{e}^{-0.000278}\right)$ decrease in the average income level for the monopolistic industries. Models 4 and 5 show that economic globalization does not have a significant impact on the average income level of the competitive sector, although the correlation was negative. Thus, Hypothesis 1a is supported.

Therefore, as China advances in its transition to a market economy, and as the country is increasingly integrated into the global market, the income advantage of the monopolistic sector has been undermined. Whether this trend will persist in the future depends on whether the government will further raise or reduce the entry barrier of the monopolistic sector. The high wages in the finance industry, for example, is largely based on preferential treatments and generous support from the government.

Three variables are controlled here: the sector's contribution to GDP, GDP of the province, and GDP per capita of the province. A positive correlation between GDP per capita of the province and sectoral income level is significant in Models 1 and 3. This means that sectoral income levels are consistent with the degree of economic development. Using a dummy variable, this research also compares the sectoral income levels before and after the 2008 financial crisis. There is a significant positive correlation between this dummy variable and sectoral income levels, implying that the financial crisis did not halt the rise of sectoral income levels for the period 2009-2014.

\section{The finance and the manufacturing industries under economic globalization}

The situation of the financial and the manufacturing sector has much to do with characteristics of economic globalization. Models 3 and 6 in Table 1 describe the relationship between economic globalization and the income levels of the financial and the manufacturing sectors. Model 3 shows a significant positive relationship between foreign trade and the income level of the finance industry: every percentage point increase in the trade-to-GDP ratio is associated with a $0.1 \%\left(=\mathrm{e}^{0.00122}-1\right)$ increase in the income level of the financial sector. In contrast, FDI significantly suppresses the income level of the manufacturing industry. Every percentage point increase in the FDI-to-GDP ratio is associated with a $2 \%\left(=1-\mathrm{e}^{-0.0178}\right)$ decrease in the income level of the manufacturing industry. In sum, globalization generates opposite effects for the financial and the manufacturing industries: it raises the income level of the finance industry and suppresses that of the manufacturing industry. Thus, Hypotheses $3 \mathrm{~b}$ and $4 \mathrm{a}$ are supported. 


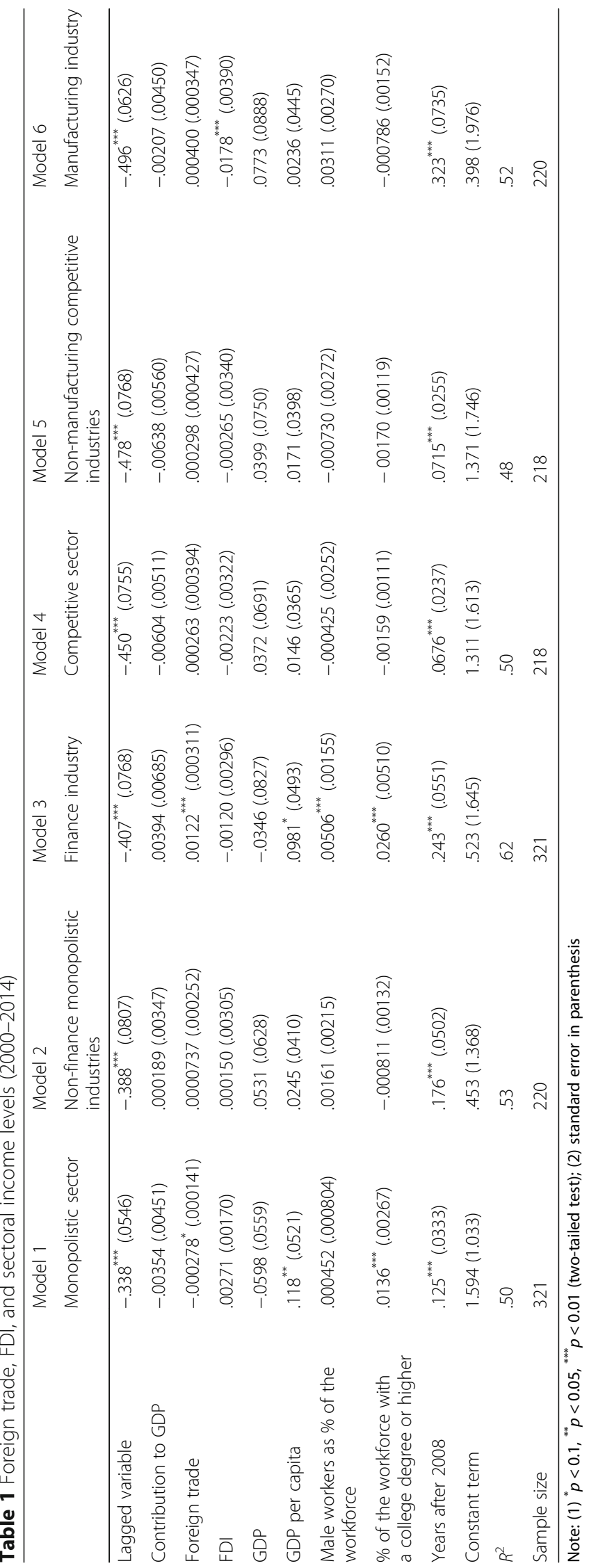


China's manufacturing sector competes globally and absorbs a large part of the economically active population. In 2014, the manufacturing sector hired 52.43 million people, which was $28 \%$ of the total urban employed population and was 10 times the size of the workforce hired by the financial sector (National Bureau of Statistics of People's Republic of China 2015, p. 115-117). The manufacturing sector mainly includes the textile industry, resource processing, and machinery and electronics manufacturing. Most of these industries are labor intensive and specialized in processing and assembling. Under the pressure to attract investment, local governments in China have formulated a large number of preferential policies in favor of foreign investors, such as guarantees of low-interest rates, government-backed collaterals, and subsidized loans (Huang et al. 2017). These measures place the national capital in a disadvantaged position in the market competition, which creates much pressure for reducing labor costs and leads to the low wage level of the manufacturing sector. This finding supports the arguments made by the dependency theory and world system theory regarding the consequences of foreign investment.

The high wages in the financial sector in China is largely the outcome of government support as a response to the risks of globalization. In the current wave of economic globalization, as a result of the changing global financial order, the financial capital is no longer limited to provide finance and service to the real economy. Rather, it has become an independent force and gained enormous profits from different countries by taking advantage of the local financial condition or the weakness in the local financial system. Because China still imposes restrictions on capital accounts and, to a certain degree, on exchange rates, the international financial capital finds it difficult to flow in and out of the country. As an alternative, the international financial capital enters China disguised as foreign trade and investment. This urges the Chinese government to support and promote the national finance industry, which has been fairly weak. The government not only consolidates the monopolistic character of the sector, but also contributes to its high profitability by reducing its debt, improving its management, and introducing advanced Western financial technology. Here, the high profitability of the finance industry in China is embodied in the high wage level of the employees in the sector.

Labor characteristics (in terms of sex and education level) are also controlled in this research. Having a high education level and being male are positively associated with the sectoral income level of various sectors. A higher education degree has the most significant impact for the finance industry: in Model 3, every percentage point increase in the percentage of the workforce with college a degree (or higher) is correlated to $3 \%\left(=\mathrm{e}^{0.026}-1\right)$ increase in the sectoral income level. In model 1 , every percentage point increase in the percentage of the workforce with a college degree (or higher) is correlated to $1.4 \%\left(=\mathrm{e}^{0.0136}-1\right)$ increase in the income level of the monopolistic sector. In comparison, for other sectors, the effect of a college degree on the sectoral income level is insignificant. In the finance industry, males' earnings have a significant advantage - on average $0.5 \% \quad\left(=\mathrm{e}^{0.00506}-1\right)$ higher-over females' earning.

This research also examines how the effect of globalization on sectoral income levels changes over time, based on models 1, 3, and 6 in Table 1. Figure 3 presents the lagged effects of foreign trade and FDI on the income level of the financial 


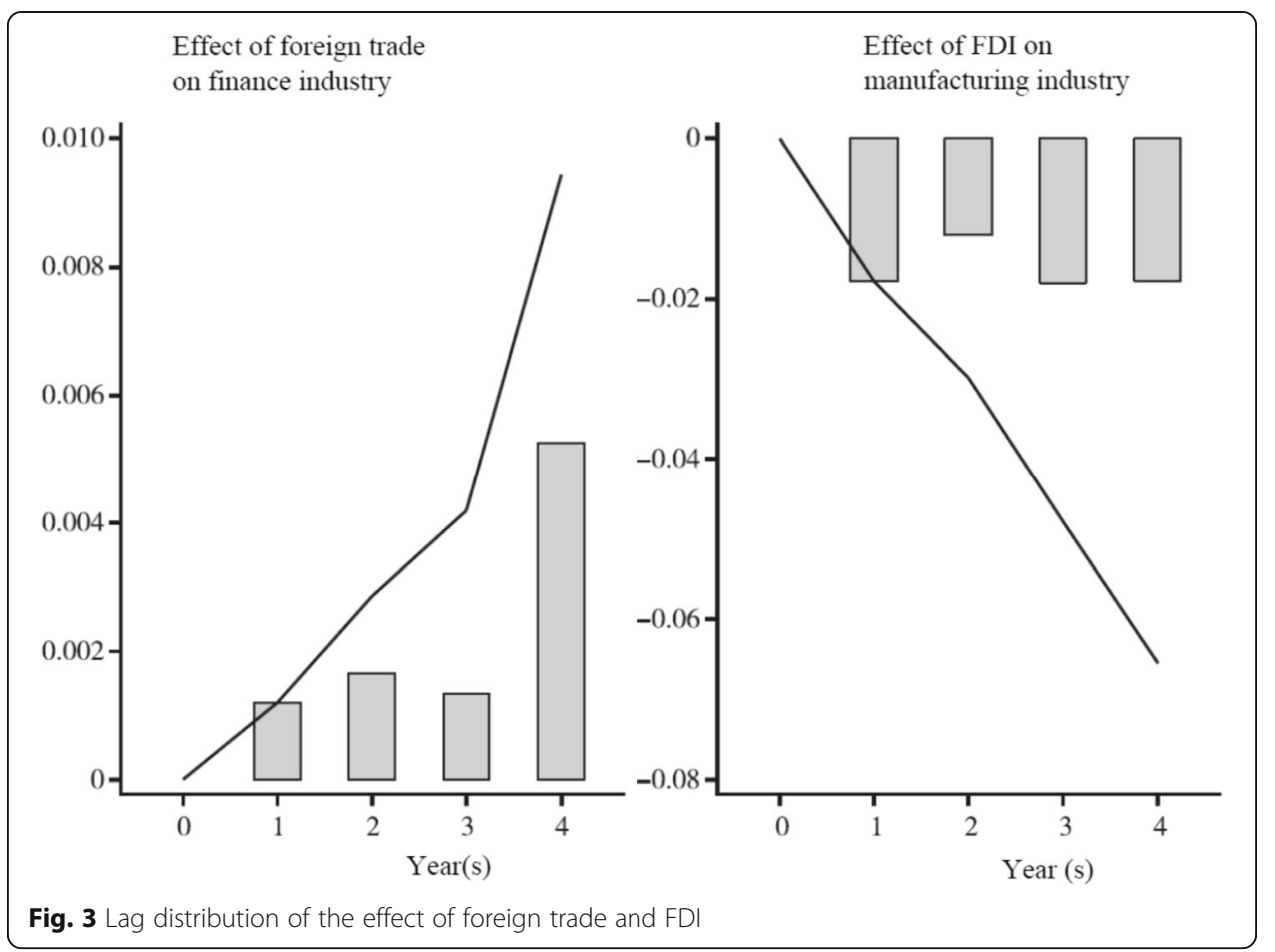

and the manufacturing industries for four consecutive years. ${ }^{10}$ The columns in the chart represent the lagged effect of each of the consecutive years, and the solid lines mark the accumulated lagged effects. It is reported that the lagged effect of foreign trade on the financial sector reaches its peak in the fourth consecutive year, and that of FDI on the manufacturing sector reaches its peak in the first consecutive year. The lagged effect of the fifth consecutive year and beyond is insignificant. The impact of economic globalization is most promptly received by the manufacturing sector. Through international competitions, the dynamics of economic globalization is quickly reflected in the welfare of its workforce. In contrast, the impacts of economic globalization on the financial sector are tardy. Since China's finance industry is largely insulated from international competition due to its monopolistic character, economic globalization only affects the sector through government policies. In other words, the impacts of economic globalization on the financial sector follow the "global market- state- finance industry" path. As it takes some time for the government to formulate policy in response to the dynamics of the international market, the effect of globalization on the financial sector reaches its maximum, not in the same year or the following year, but 4 years later.

\section{Effects of economic globalization on eastern China and western China}

The market transition in China unfolded unevenly in the country. It was first promoted in the coastal region in the east, and then in the interior provinces in central and western China. One consequence of this policy approach is that eastern China received much more foreign trade and FDI than western China. As shown in Fig. 4, between 2000 and 2014, foreign trade averaged $56-83 \%$ of the GDP in the eastern provinces, 


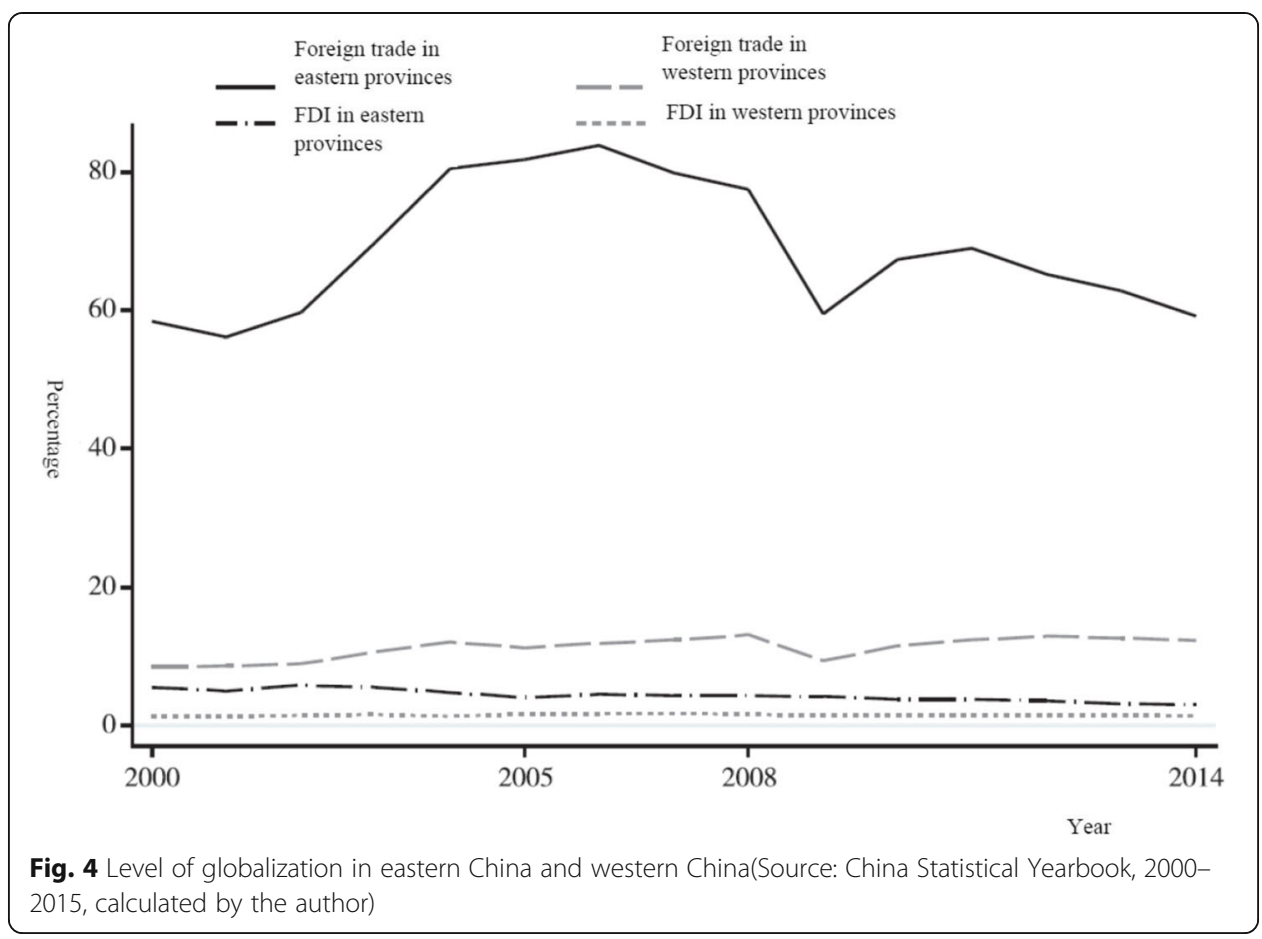

but only $8-13 \%$ in the western provinces. The geographic distribution of FDI shows a similar pattern: FDI averaged about $3-5 \%$ of the GDP in eastern provinces, which is 3 to 5 times higher than in the western provinces.

This article underscores the effect of economic globalization on the average income level of the monopolistic sector, as well as the finance and the manufacturing industries. Yet, does this effect only apply to the eastern provinces, where the economy is more integrated into the global market? Or does it also apply to the western provinces?

In Tables 2 and 3, the sample used in this research is disaggregated into two subsamples-one for the eastern provinces and the other for the western provinces. ${ }^{11}$ Using the same regression method, we examined the impacts of globalization on these two regions. The results confirm that the aforementioned effect of economic globalization on sectoral income levels exist for both the eastern region and the western region. First, foreign trade has a significant negative correlation with the income level of the monopolistic sector in both the eastern and the western provinces. Each percentage point increase of the trade-to-GDP ratio is associated with a $0.03 \%\left(=1-\mathrm{e}^{-0.000299}\right)$ decrease in the income level of the monopolistic sector in eastern provinces, and a $0.04 \%(=1-$ $\mathrm{e}^{-0.0004}$ ) decrease in the western provinces (models 7 and 13). Second, economic globalization has not significantly affected the income level of the competitive sector in neither the eastern region nor the western region. Third, FDI has suppressed the wage level of the manufacturing industry in both the eastern and the western provinces. Each percentage point increase of the FDI-to-GDP ratio is correlated to $1.7 \%\left(=1-\mathrm{e}^{-0.0170}\right)$ decrease in the income level of the manufacturing sector in the eastern region and $2 \%$ $\left(=1-\mathrm{e}^{-0.0203}\right)$ decrease in the western region (models 12 and 18). Only in the eastern provinces does foreign trade have a significant positive correlation with the income level of the financial sector (model 9), whereas this correlation is not significant in the western region. This is the only difference that distinguishes the two subsamples. 


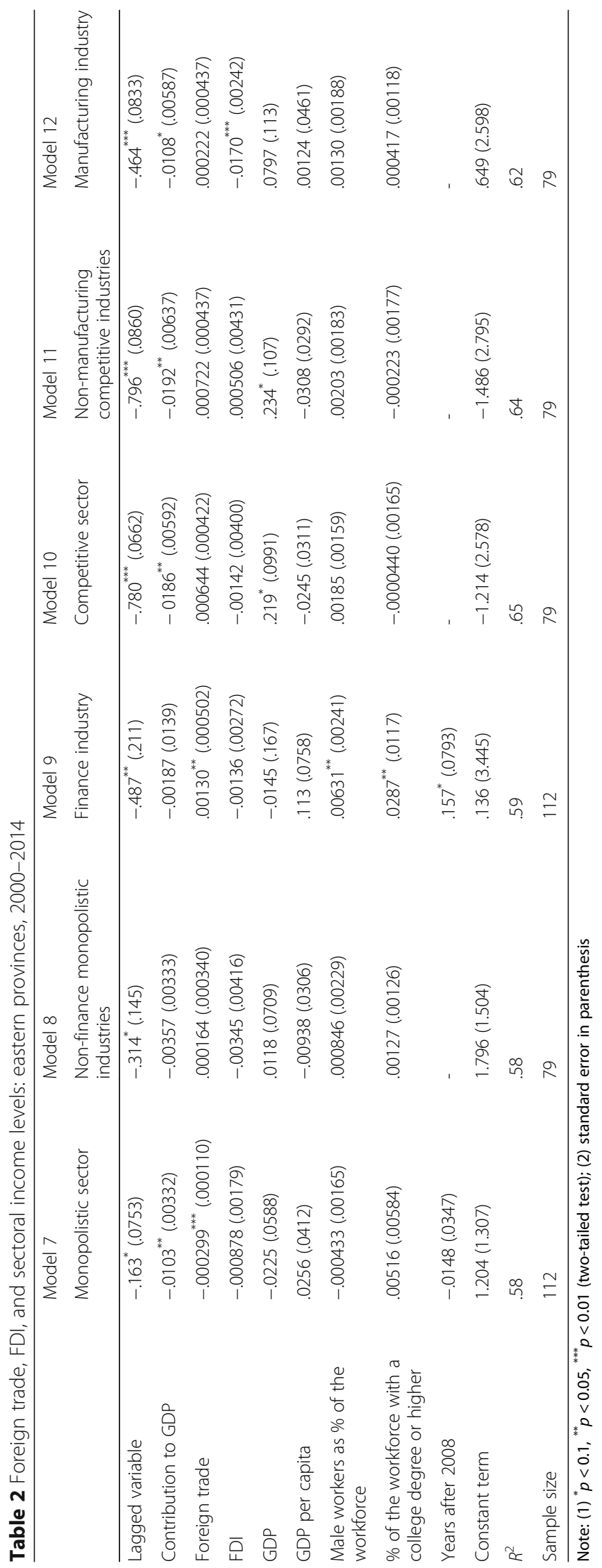




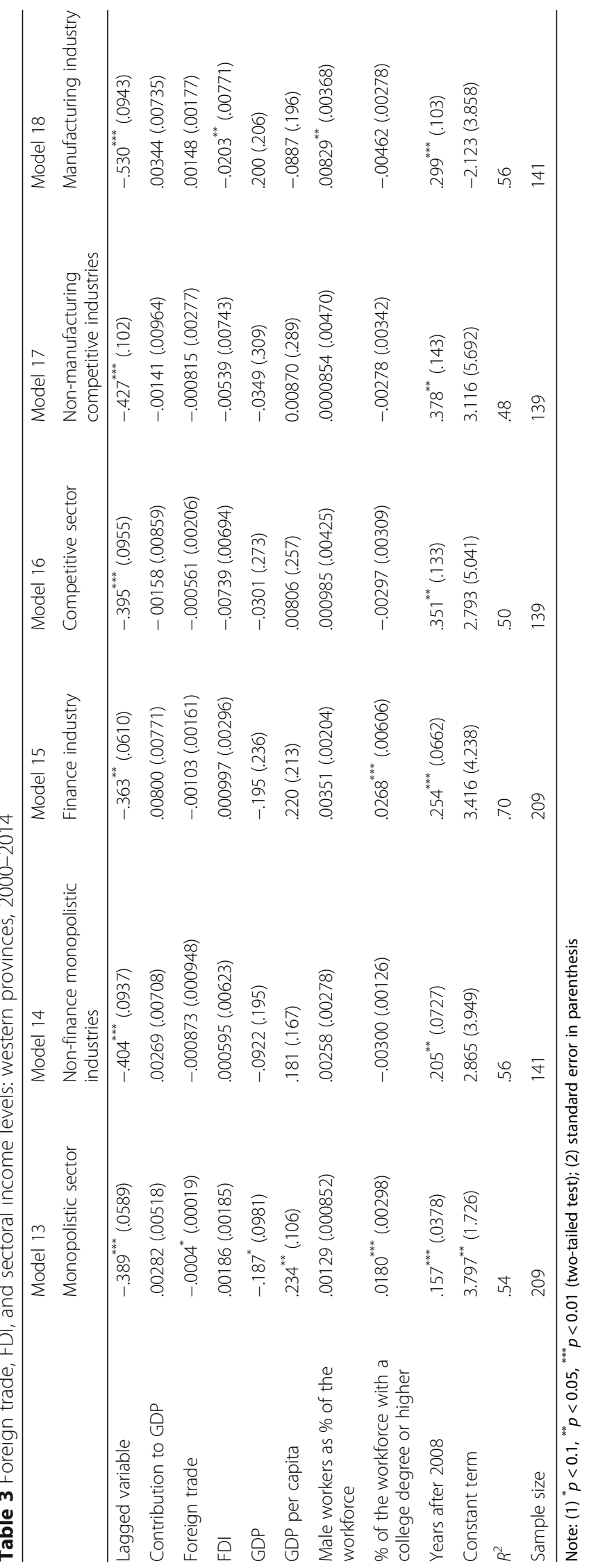


The consistency of the findings on the effects of globalization in eastern China and in western China is evidence of the robustness of this research. It also shows that sectoral income levels in the eastern provinces and the western provinces are embedded in a similar institutional context. Although western China is less advanced in its integration in the global market compared to the east, they both face the same configuration of international competition, and in both regions, the finance industry has received enormous support from the government. Thus, in both regions, economic globalization has a significant negative correlation with sectoral income levels.

\section{Conclusions}

The perspective of segmented labor market cannot satisfactorily explain why finance is the highest paying industry within the monopolistic sector, and why wages in the manufacturing industry are relatively low within the competitive sector. This research shows that income inequalities among industries should be understood in the context of economic globalization. Based on the provincial panel data for the years 2000-2014, this article argues that economic globalization has suppressed the income level of the manufacturing industry (Hypothesis 3) and raised the income level of the finance industry (Hypothesis 4). Meanwhile, economic globalization has also lowered the income level of the entire monopolistic sector, although its effect on the competitive sector was not significant (Hypothesis 1). In sum, the Hypotheses 1, 3, and 4 are supported to different extents.

This research shows that economic globalization has somehow shaped the segmentation of the labor market in China. This effect unfolds through government industrial policies. First, based on the comparative advantage of a cheap labor force, China's manufacturing sector was inserted into the global market early on. The global competition forces the sector to suppress its wage level. Second, given the weakness of the national financial sector and the growing risks of the international financial market, the Chinese government heavily protects the country's finance industry. This is in sharp contrast to the situation of the manufacturing sector, which has completely opened up to the global market. The increasing monopolistic character of China's finance industry is accompanied by the high wage level of the sector. Third, although the government protects key industries by establishing barriers to entry, the increasing competition introduced by the economic globalization has somehow suppressed the income level of the monopolistic sector.

Regarding the causes of income inequality in China, existing research suggests that these are embedded in the intersection of the market and non-market factors (Chen 2010). This article supports this view: how the global market impacts the country depends on government industrial policies, as well as the related institutional arrangements. In other words, non-market factors consist of the basis for the market to have impacts.

This research intends to systematically analyze how economic globalization impacts inequality, which has not been adequately addressed in existing sociological research. The mainstream economic literature tends to view economic globalization as a market process, and focus on how it impacts productivity, technological innovation and profits (Wang 2016; Ye and Wang 2014). Yet, this perspective overlooks that globalization is also a political and social process and that its effect is mediated by government policies 
(Alderson and Nielsen 2002; Bandelj 2009). This article concludes that how globalization affects sectoral income levels has much to do with how government shapes the market. In other words, the government plays an intermediary role in this process. Therefore, to understand the consequences of globalization, it is important to consider the role of the state, rather than only considering the market.

This research has some limitations as well. The available data do not allow us to examine the income distribution within the industry-for example, the income inequality between administrative personnel and regular workers, or the impacts of party affiliation on income. When we examined the impacts of the foreign capital, we were unable to distinguish the capital from Hong Kong, Macau, and Taiwan and the capital from other regions. To close these gaps, it will require more data.

\section{Endnotes}

${ }^{1}$ In 1955 and 1963, the Agricultural Bank of China was reestablished twice. Yet, in both occasions, its existence was rather ephemeral and was soon reincorporated into the People's Bank of China. The People's Insurance Company of China was founded in 1949, but the insurance business was abolished in the country in 1959. Its remnant foreign business was transferred to the Foreign Office of the People's Bank of China, and it should not be viewed as an independent financial institution.

${ }^{2}$ Data source: Yearbook of China's Finance and Banking, 1992-1998.

${ }^{3}$ Including Shanghai Pudong Development Bank, Industrial Bank, Bank of Communications, China Merchants Bank, etc.

${ }^{4}$ Foreign banks are subject to geographic restrictions in China. They are not authorized to run renminbi business or issue bank cards/passbooks. Restrictions are also imposed on the financial products and services they can engage in. Although in theory these restrictions have been relaxed in recent years, foreign banks are still not in the same position to compete with Chinese banks.

${ }^{5}$ The Central Bank relaxed the restrictions over loan interest rates in July 2013 and interest rates for saving accounts in October 2015. These events represent a milestone in the marketization of interest rates in China. Yet, the Central Bank still determines the lower limit of the loan interest rates and the upper limit of the interest rates for saving accounts. To a certain extent, interest rates in China are still controlled by the government.

${ }^{6}$ This research also uses the number of inbound tourists and inbound tourists' per capita expenses as instrument variables to measure the level of foreign trade and FDI. The results still hold. These two variables pass the test for weak instruments (15\% level) and thus can be considered as exogenous. However, the result of Sargan test shows some significant correlation between these two variables with the disturbance item. Please contact the author for a more detailed analysis.

${ }^{7}$ Due to page restrictions, this article does not present the descriptive statistics in detail. Please contact the author if interested in these statistics.

${ }^{8}$ Yue's team (Yue et al. 2010) only studied the monopolistic industries that participated in market competition, and thus excluded sectors of (1) education, health care, and social work; (2) public administration, social insurance, and social organizations; (3) culture, sports, and entertainment; and (4) scientific research and technical services. They also included the agricultural and sideline products processing industry in their 
analysis of the competitive sector. We ran analysis based on the classification used by Yue's team, and the previous results still hold.

${ }^{9}$ In Tables 1, 2, and 3, fixed effects of the provinces and years are simultaneously controlled, and the clustered standard errors are calculated. Regarding Table 1, we also run two regression models, one in which only the province fixed effects are controlled and the other in which only the year fixed effects are controlled. The previous results still hold.

${ }^{10}$ The effect of foreign trade on the income level of the monopolistic sector is significant only within the first year. Thus, Fig. 3 only reports the effect of foreign trade and investment on the finance and the manufacturing industries.

${ }^{11}$ According to the common classification used in existing research (such as Jia and Kong 2015), in this article, the "eastern region" includes eight provinces, namely, Jiangsu, Zhejiang, Guangdong, Fujian, Shandong, Liaoning, Hebei, and Hainan, as well as three direct-administered municipalities, namely, Beijing, Shanghai, and Tianjin. All the other provinces and direct-administered municipalities are considered to be in the "western region."

\section{Abbreviation}

FDI: Foreign direct investment

\section{Acknowledgements}

The findings of this research were presented in the bi-weekly seminar of the Department of Sociology of Fudan University, as well as in the 2017 Annual Conference of the Chinese Sociological Association. The author would like to thank scholars including Liu Xin, Hu Anning, Huang Ronggui, Tian Feng, Wu Fei, Ji Yingying, Fan Xiaoguang, Feng Shizheng, Song Xi, Li Guowu, Zhao Yandong, and Hong Yanbi, as well as the anonymous reviewers, for their constructive feedback on this essay. However, the author assumes all the responsibilities for the findings and arguments in this article.

\section{Author's contributions}

The sole author $\mathrm{XL}$ contributes to the paper independently. The author read and approved the final manuscript.

\section{Funding}

This research is supported by Fudan University's "Double First-Class" Innovation Project "Sociological Theory and Research on Social Transformation".

\section{Availability of data and materials}

The data used in this manuscript are merged from several sources: (1) province-level yearbook of China from 2001 to 2015; (2) China Statistical Yearbook 2000-2015; (3) China Population and Employment Yearbook 2000-2015.

\section{Competing interests}

The author declares that she has no competing interests.

Received: 25 March 2019 Accepted: 17 June 2019

Published online: 03 July 2019

\section{References}

Alderson, A.S., and F. Nielsen. 2002. Globalization and the great U-turn: Income inequality trends in 16 OECD countries. American Journal of Sociology 107 (5): 1244-1299.

Bandelj, N. 2009. The global economy as instituted process: The case of central and Eastern Europe. American Sociological Review 74 (1): 128-149.

Bao, Q., and M. Shao. 2008. Foreign investment and wage differences in the host country: An empirical research on China's industrial sector. Management World 5: 46-54

Bao, Q., M. Shao, and W. Hou. 2011. Does export cause higher wage? Economic Research Journal 46 (9): 41-54.

Bian, Y., and J.R. Logan. 1996. Market transition and the persistence of power: The changing stratification system in urban China. American Sociological Review 61 (5): 739-758.

Brady, D., M. Seeleib-Kaiser, and J. Beckfield. 2005. Economic globalization and the welfare state in affluent democracies, 1975-2001. American Sociological Review 70 (6): 921-948.

Carruthers, B., and J. Kim. 2011. The sociology of finance. Annual Review of Sociology 37: 1-21.

Chen, G. 2010. Market or non-market? An empirical analysis of the main causes of income inequalities in China today. Sociological Studies 6: 86-115.

Curwin, K.D., and M.C. Mahutga. 2014. Foreign direct investment and economic growth: New evidence from post-socialist transition countries. Social Forces 92 (3): 1159-1187. 
Dixon, W.J., and T. Boswell. 1996. Dependency, disarticulation, and denominator effects: Another look at foreign capital penetration. American Journal of Sociology 102 (2): 543-562.

Feenstra, R.C., and G.H. Hanson. 1997. "Productivity measurement and the impact of trade and technology on wages: Estimates for the US, 1972-1990." NBER Working Paper No. 6052.

Fligstein, N. 2001. The architecture of markets. Princeton: Princeton University Press.

Guan, X. 2002. WTO, globalization, and China's social welfare reform. China Social Welfare 1: 11-15.

Haggard, S., and R. Kaufman. 2008. Development, democracy, and welfare states: Latin America, East Asia, and Easter Europe. Princeton: Princeton University Press.

Hai, W. 2001. Admission to WTO and its impacts on China. Information for Deciders Magazine 20: 20.

Han, J., R. Liu, and J. Zhang. 2012. Globalization and wage inequality: Evidence from urban China. Journal of International Economics 87 (2): 288-297.

Hao, D., and L. Li. 2006. State monopoly and income inequality in regional disparity reform: Based on National Comprehensive Social Survey Data 2003. Social Sciences in China 2: 110-124.

Huang, S., L. Wu, and C. Wu. 2017. Does FDI competition have debt financing 'crowding out' effect? The Journal of Quantitative \& Technical Economics 1: 130-145.

Jensen, N.M., and G. Rosas. 2007. Foreign direct investment and income inequality in Mexico, 1990-2000. International Organization 61 (3): 467-487.

Jia, Y., and F. Kong. 2015. Human capital accumulation, financial development and FDI: An empirical analysis based on provincial panel data of China's eastern region. Journal of Xi'an University of Finance and Economics 6: 31-35.

Jiang, Q., and R. Li. 2010. The relationship between trade structure and manufacture industrial structure. On Economic Problems 5: 19-23.

Kentor, J. 2001. The long term effects of globalization on income inequality, population growth, and economic development. Social Problems 48 (4):435-455.

Li, J., and Y. Gu. 2011. Hukou-based stratification in China's urban labor market. Sociological Studies 2: 48-77.

$\mathrm{Li}, \mathrm{J}$., and H. Zeng. 2009. The relationship between FDI spillover and economic growth: A study based on the financial market development with panel data of Chinese provinces. Statistical Research 3: 30-37.

Li, L., B. Zhu, and Y. Wang. 2016. Market transformation, labor market segmentation and organizational work flow. Social Sciences in China 9: 126-145.

Lim, A., and K. Tsutsui. 2012. Globalization and commitment in corporate social responsibility: Cross-National Analyses of institutional and political-economy effects. American Sociological Review 77 (1): 69-98.

Liu, B., and L. Li. 2012. Trade openness and the gender wage gap. China Economic Quarterly 2: 429-460.

Luo, C., and S. Li. 2007. The human capital, the characteristics and the inequality in income of industries. Management World 10: 19-30.

Manova, K. 2012. Credit constraints, heterogeneous firms, and international trade. Review of Economic Studies 80 (2): 711-744. National Bureau of Statistics of People's Republic of China. 2015. China statistical yearbook. Beijing: China Statistics Press.

Nee, V. 1989. A theory of market transition: From redistribution to markets in state socialism. American Sociological Review 54 (5): 663-681.

Nee, V. 1991. Social inequalities in reforming state socialism: Between redistribution and Markets in China. American Sociological Review 56 (3): 267-282.

Nee, V. 1996. The emergence of a market society: Changing mechanisms of stratification in China. American Journal of Sociology 101 (4): 908-949

Qi, Y., and T. Liang. 2016. Regional difference or industrial difference? Dual labor market segregation and income inequality in China. Sociological Studies 1: 168-190.

Rona-Tas, A. 1994. The first shall be last? Entrepreneurship and communist cadres in the transition from socialism. American Journal of Sociology 100 (1): 40-69.

Song, S. 2008. History of the market-oriented reform of China's banking industry. Researches in Chinese Economic History 4: 33-42.

Sorensen, Aage B. 2000. Toward a Sounder Basis for Class Analysis. American Journal of Sociology 105(6): 1523-1558.

Tomaskovic-Devey, D., and K.H. Lin. 2011. Income dynamics, economic rents, and the Financialization of the US economy. American Sociological Review 76 (4): 538-559.

Wallerstein, I.M. 1974. The modern world-system, Vol. 1: Capitalist agriculture and the origins of the European world-economy in the sixteenth century. New York: Academic.

Wang, B. 2016. Ownership structure of FDI and effect of technology spillover. Journal of Commercial Economics 22: 174-176.

Wang, S. 2001. Opening up and inequalities: Can China compensate losers from its admission to WTO? Management World 6: $14-25$.

Wang, S. 2014. The nature of the hierarchy and the boundary of the financial marketization in China: Focus on the SME financing assurance. Sociological Review of China 2: 35-47.

Wang, T., and X. Cui. 2010. How does industry influence income distribution? Results of HLM analysis. Social Sciences in China 5: $165-180$

Wang, Y., and C. Luo. 2012. China's labor market development based on economic transform. Journal of Renmin University of China 3: 75-82.

Wei, S. 2002. Economic globalization and income differential. In National Bureau for Economic Research Working Paper.

Wu, Y. 2011. Labor market segmentation, job mobility and the two-track model of Chinese urban workers' acquisition of economic status. Social Sciences in China 1: 119-137.

Xie, P., and L. Yin. 2002. "Research on the Efficiency of China's Financial System." Working Paper, Shanghai Stock Exchange Joint Research Project, Third Phase.

Xie, Y., and E. Hannum. 1996. Regional variation in earnings inequality in reformera urban China. American Joumal of Sociology 101 (4): $950-992$.

$\mathrm{Xu}, \mathrm{Y}$. 2003. Trade liberalization and transformation of income distribution in China. World Economic Forum 4: 44-54.

Yang, D. 2018. Financial globalization and the transnational diffusion of shareholder-oriented corporate governance institutions: A sociological analysis of corporate governance reform in China. Chinese Journal of Sociology 2: 112-136.

Ye, J., and J. Wang. 2014. Effects of FDI on China's technological innovation: An empirical test based on 2002-2011 panel data of Jiangsu Province. Journal of International Trade 1: 131-138. 
Yuan, X. 2010. China's foreign trade structure and industrial structure: Deviation of Mirror image from original image. Economist 6: 67-73.

Yue, X., S. Li, and T. Sicular. 2010. Are the high salaries of employees in monopoly industries justified? Social Sciences in China 3: 77-93.

Zhang, J., and W. Guo. 2004. Why do foreign companies enter the Chinese market via FDI instead of purchase orders? Finance \& Trade Economics 1: 33-38.

Zhang, Z. 2004. Sectoral segmentation of labor markets and the labor mobility. Population Science of China 2: 47-54.

Zhao, D., and Y. Zhang. 2013. Research on foreign trade, FDI and income distribution. Productivity Research 3: 31-34.

Zhao, Y. 2003. China's opening up and income inequality. World Economic Forum 4: 55-70.

Zhou, Z. 2007. Study on the China's financial system reform since the reform and the opening up. In Doctoral dissertation, Northeast Normal University.

Publisher's Note

Springer Nature remains neutral with regard to jurisdictional claims in published maps and institutional affiliations.

Submit your manuscript to a SpringerOpen ${ }^{\circ}$ journal and benefit from:

- Convenient online submission

- Rigorous peer review

- Open access: articles freely available online

High visibility within the field

- Retaining the copyright to your article

Submit your next manuscript at $\boldsymbol{\nabla}$ springeropen.com 